\title{
Correction to: Forecasting International Sugar Prices: A Bayesian Model Average Analysis
}

\author{
El Mamoun Amrouk ${ }^{1,2}$ - Thomas Heckelei ${ }^{1}$
}

Published online: 20 August 2021

(c) Society for Sugar Research \& Promotion 2021

Correction to: Sugar Tech (July-Aug 2020) 22(4):552-562

https://doi.org/10.1007/s12355-020-00815-0

The article: Forecasting International Sugar Prices: A Bayesian Model Average Analysis, written by El Mamoun Amrouk $^{1,2}$ and Thomas Heckelei ${ }^{1}$, was originally published electronically on the publisher's internet portal (currently SpringerLink) on 21 April 2020 without open access.

With the author(s)' decision to opt for Open Choice, the copyright of the article changed on 29 July 2021 (C) The Author(s) 2021 and the article is forthwith distributed under the terms of the Creative Commons Attribution 4.0 International License (http://creativecommons.org/ licenses/by/4.0/), which permits use, duplication, adaptation, distribution, and reproduction in any medium or format, as long as you give appropriate credit to the original author(s) and the source, provide a link to the Creative Commons license, and indicate if changes were made.
The original article was corrected.

Open Access This article is licensed under a Creative Commons Attribution 4.0 International License, which permits use, sharing, adaptation, distribution and reproduction in any medium or format, as long as you give appropriate credit to the original author(s) and the source, provide a link to the Creative Commons licence, and indicate if changes were made. The images or other third party material in this article are included in the article's Creative Commons licence, unless indicated otherwise in a credit line to the material. If material is not included in the article's Creative Commons licence and your intended use is not permitted by statutory regulation or exceeds the permitted use, you will need to obtain permission directly from the copyright holder. To view a copy of this licence, visit http://creative commons.org/licenses/by/4.0/http://creativecommons.org/licenses/ by $/ 4.0 /$.

Publisher's Note Springer Nature remains neutral with regard to jurisdictional claims in published maps and institutional affiliations.

The original article can be found online at https://doi.org/10.1007/s12355-020-00815-0.

El Mamoun Amrouk elmamoun.amrouk@fao.org

1 Institute for Food and Resource Economics, University of Bonn, Nußallee 21, 53115 Bonn, Germany

2 Food and Agriculture Organization of the United Nations (FAO), Vialle delle Terme di Caracalla, 00153 Rome, Italy 